Economics Working Paper 139

\title{
Transfers, Social Safety Nets, and Economic Growth*
}

\author{
Xavier Sala-i-Martin \\ Yale University and Universitat Pompeu Fabra
}

September 1995

Keywords: Social safety nets, public welfare, economic growth, transfers, productive public spending.

Journal of Economic Literature classification: H53, H55, H56, O40, O15.

* While writing this paper I have benefited from conversations with Robert Barro, Albrecht Ritschl, Willem Buiter, Paul Cashin, Daniel Cohen, Larry Katz, Elvinticinc Dedesembre, Fumfum Fum, Chris Sims, Etsuro Shioji, and Joel Waldfogel. This research has been partly supported by the Instituto de Estudios Fiscales in Madrid and was concluded while I was visiting the research department at the International Monetary Fund. 


\begin{abstract}
The role of social safety nets in the form of redistributional transfers and wage subsidies is analyzed using a simple model of criminal behavior. It is argued that public welfare programs act as a crime-preventing or disruptionpreventing devices because they tend to increase the opportunity cost of engaging in crime or disruptive activities. It is shown that, in the presence of a leisure choice, wage subsidies may be better than pure transfers.

Using a simple growth model, it is shown that it is not optimal for the government to try to fully eliminate crime. The optimal size of the public welfare program is found and it is argued that public welfare should be financed with income (not lump-sum) taxes, despite the fact that income taxes are distortionary. The intuition for this result is that income taxes act as a user fee on congested public goods and transfers can be thought of as productive public goods subject to congestion.

Finally, using a cross-section of 75 countries, the partial correlation between transfers and growth is shown to be significantly positive.
\end{abstract}




\section{INTRODUCTION.}

In the last quarter of the XIX century, as the leading nations of Europe and North America emerged from the throes of the industrial revolution, the introduction of social safety nets was increasingly regarded as a social necessity. The sight of poverty amongst plenty, of need amidst unused resources, made societies feel that the government should take over the role of helping the destituted. Traditionally, the job of protecting the poor was taken by religious foundations, extended families, or good-hearted criminals like Robin Hood or Curro Jiménez. But, following Chancellor von Bismarck's lead, public welfare programs were instituted in virtually all countries. For almost a century, it was almost an unquestioned reality that the public sector had the moral and actual obligation to provide social protection. And so social security programs grew larger and larger all over the world. Today, public transfers in the United States account for almost one half of all federal spending and involve three times as much money as public investment and more than twice as much as national defense. International institutions like the World Bank or the International Monetary Fund spend a great deal of time and effort worrying about the effects of their programs on the very poor and wonder about how to introduce social safety nets in the countries experiencing economic transitions (IMF (1993), Chu and Gupta (1993).)

A century after the introduction of social security in Imperial Germany, the conservative movement lead by Ronald Reagan in the United States and Margaret Thatcher in Europe introduced doubts in the minds of many citizens as to the desirability of public welfare programs. Questions like "what are the benefits of social security?" and "how large should public welfare programs be?" have replaced the widely held belief that "society" (and, on its behalf, the 
government) should protect the destituted and that more security is always better.

Whether to have social security programs and, if so, how big should they be are important questions. These questions, however, cannot be answered until we understand why such programs exist in the first place. Several stories have been provided as probable explanations of the existence of public welfare programs. The simplest one is that of social altruism: human societies dislike the sight of poverty amongst wealth (Stark (1995).) Alternative explanations are based on median voter behavior (the median voter is poor and votes himself a big transfer, or the median voter gives a transfer to the poor in order to buy his vote; see Persson and Tabellini (1991) and Tabellini(1992).) Although these are potentially interesting theories, I will not pursue them here. For example, it is hard to understand why we, the society, love the poor of our country but do not care much about the poor of other nations. Furthermore, social security programs exists in all countries, and not only in demooratic regimes. But the important reason is that, as it will be shown in the empirical section of the paper, transfers are positively correlated with the growth rate of the economy. ${ }^{1}$ It appears, therefore, that transfers look very much like a productive public input. ${ }^{2}$ If transfers are devices that satisfy social altruism or if they are big selfimposed gifts voted by the median voter, they should not have any effect on growth. Furthermore,

${ }^{1}$ This puzzling positive correlation was first found by Barro (1991b) and it has subsequently been documented by Cashin (1995).

${ }^{2}$ A substantial fraction of the recent growth literature deals with the role of government in the process of economic development. Chamley (1981), Lucas (1990) and the subsequent literature deal with the problem of optimal taxation. For example, Barro (1990), Barro and Sala-I-Martin (1992 and 1995, ch. 4), Gloom and Ravikumar (1994), and Cashin (1995) among others, present models where the productive aspects of public spending are offset by distortionary taxes. The literature has devoted little attention to transfers and their role in the process of economic growth. This is surprising given the size of public transfers relative to other forms of public spending like public investment or infrastructure. 
if, as they are in the real world, they are financed with distortionary taxes, then they should have a negative effect on growth.

In this paper I provide an alternative rationale for the existence of public welfare programs ${ }^{3}$ and their relation to economic growth. The main point of this paper is that transfers and other social safety net mechanisms are a means to buy social peace, a way to reduce social unrest. They are a way to bribe poor people out of activities that are socially harmful, such as crimes, revolutions, riots and other forms of social disruption. ${ }^{4}$

This idea is not new. In fact, von Bismarck himself has been quoted as saying that the main reason for him introducing the social security program was to keep the socialist movement out of imperial Germany. ${ }^{5}$ Nevertheless, the paper makes some contributions to the literature of social security. First, it shows that public welfare programs may reduce social disruptions.

Second, these programs may actually increase the growth rate of the economy, even if they are

${ }^{3}$ Most of the transfers taking place in rich industrialized nations are not between rich and poor but between young and old. In the present paper I analyze transfers between rich and poor Old-age transfers are analyzed in Sala-I-Martin (1995). In that paper I argue that old-age transfers appear to be productive because they are a means to bribe the old, unproductive, workers out of their jobs. In the presence of human capital externalities like those proposed by Lucas (1988), the elimination of the elderly from the labor force will increase the level of income of the economy as well as its growth rate.

4 It can persuasively argued that, when the World Bank or the IMF worry about social safety nets in transition economies, they do so (at least partly) to ensure the success of the transition process. If too large a fraction of people become destituted in the process of transition, riots, revolutions or military coups may actually end with a program that would have been beneficial in the long run.

5 Encarta's Encyclopedia, for example, after describing him as a ruthless politician who fought any and all who questioned his policies, says that "although he failed to defeat the Socialists, the social security legislation he introduced-national accident and health insurance and old-age pensions - ended whatever revolutionary designs they may have had". 
financed with distortionary taxes. Third, public welfare spending may look like public productive spending subject to congestion. And fourth, as a result of the third finding, financing social security with income taxes is superior to financing them with non-distortionary taxes.

The rest of the paper is organized as follows. In the Section III, I present a partial equilibrium model where people choose the amount of time they want to devote to criminal activities. The model is in the spirit of Becker (1968) and Ehrlich (1970) but, unlike them, I do not try to determine what are the optimal policies to combat illegal behavior (such as the optimal severity of punishment or the optimal size of penalties for different types of crimes). The goal of this section is to show that transfers and other forms of social safety nets act as devices that reduce the incentive to commit crimes, because they increase the amount of income one can legally receive outside jail. I show that these results are robust to the inclusion of leisure, even though economic intuition says that transfers unrelated to work effort could have a perverse effect on criminal intensity.

One of the key results from the first section is that the decision to commit crimes is based on the size of transfers relative to the average level of income of the economy. Hence, in the aggregate economy, transfers look very much like a public good subject to congestion: when a person increases his income, so does the average income of the economy. This increases the reward to criminal behavior and, with it, the protective role of transfers is congested.

In section III, I incorporate the analysis into an aggregate model of growth. This allows me to determine the growth-maximizing amount of public welfare in the economy as the government balances the beneficial, protective effects of transfers and wage subsidies with the adverse effects of the distortionary taxes needed to finance such programs. I also show that the 
government can replicate the planner's solution by using income taxes and not lump sum taxes. The intuition is that income taxes act like 'user fees' on the protective role of the public welfare policies.

In Section IV, I present empirical evidence on the positive relation between transfers and growth. This positive relation should puzzle those who believe that transfers are the outcome of social altruism. The final section concludes.

\section{A PARTIAL EQUILIBRIUM MODEL OF CRIMINAL BEHAVIOR.}

The model I use to analyze transfers extends Becker (1968) and Ehrlich (1970). Let $t_{i}$ be the fraction of time an individual devotes to illegal, criminal or disruptive activities such as thefts, robberies, strikes or revolutions. After normalizing total non-leisure disposable time to one, the time devoted to legal activities is $1-\mathrm{t}_{\mathrm{i}}$. The reward for devoting one unit of time to a legal activity (work) is the wage rate $w$. The reward for engaging in criminal activity is $\beta y$ per unit of time where $y$ is the average income of the economy and $\beta$ is a number between zero and one. If we argue that criminal activity is akin to mugging people on the street, and that the average person carries a fraction $\beta$ of his income in his pocket ${ }^{6}$, then $\beta \cdot y$ is the reward per unit of time devoted to crime, and $\beta \cdot y \cdot t_{i}$ is the reward for criminals who choose to devote $t_{i}$ units of their time to this

6 This fraction $\beta$ could be thought of as being chosen by the average person according to some money demand model that I do not need to specify here. It should be noted that, when making this choice, this person will take into account the probability of being mugged and will add it to the interest foregone by holding cash. That is, the larger the number of criminals operating in a certain area, the lower is likely to be the reward per unit of time devoted to crime since people living or working in that area will be careful not to carry too much money in their pockets. 
activity. I will assume that the only purpose of crime is to obtain the monetary reward. Unlike Becker (1968), agents in my model do not engage in criminal activities simply because they like crime. $^{7}$ Utility is here solely a function of consumption.

Society, through its government, has access to some technology to capture and prosecute criminals. I will assume that the probability of a criminal being caught and convicted is $\pi$. This probability should be an increasing function of the effort the government puts into enforcing laws. It could also be thought to be an increasing function of the amount of crime committed by any given person. In this first simple model, however, I will assume that $\pi$ is independent of the amount of crimes people choose to commit. ${ }^{8}$ I will relax this assumption later on. Stigler (1970) shows that if law enforcement is costly, there is an optimal amount of enforcement which may be lower than the maximum allowed by the current technology. Hence, the probability of capture need not be one, even though achieving such probability may be technologically feasible. We can simply think of $\pi$ as the probability of capture and conviction given by the existing technology and the optimal level of public effort.

7 Becker uses this assumption to explain passion crimes and other crimes that entail no direct monetary reward to criminals. Another unrealistic assumption is that all persons in the economy have the same attitude or preference for crime. Different people may perceive crime differently and these differences may be due to educational background and/or religious beliefs.

${ }^{8}$ One could argue that there is learning by doing (or learning by offending): people who commit few crimes are naive and are more likely to be caught. Professional criminals, on the other hand, have more experience and know how evade police more easily. Furthermore, full-time criminals may be able to bribe policemen and judges in order to lower their probability of conviction. The offsetting force is that the more crimes you commit, the more likely the police are to devote their efforts to capture you in particular (while if you are a naive part-time criminal, the police are likely to either ignore you or to spend little effort in trying to capture you). In this simple model I will assume that these forces roughly offset one another and that the probability of being convicted is independent of $t_{i}$. 
Individual's preferences can be represented by the following expected utility function:

$$
\text { (1) } U=\pi \cdot \ln \left(c^{p}\right)+(1-\pi) \cdot \ln \left(c^{n p}\right) \text {, }
$$

where $c^{p}$ is the level of consumption if he is caught and convicted ( $p$ stands for 'penalized') and $c^{n p}$ is the level of consumption if he is not penalized.

The level of income if he is not convicted is equal to legal work income, $w \cdot\left(1-t_{i}\right)$, plus the income he gets from his criminal activities, $\beta \cdot y \cdot t_{i}$. I will further assume that there is a public welfare system in the economy. Public welfare could take the forms of either a lump-sum transfer $\mathrm{T}$, or a subsidy on the wage, $\mathrm{w}^{9}$ Given that the model is static in nature, all income is consumed so the level of consumption if not convicted is

$$
\text { (2) } c^{n p}=w \cdot\left(1-t_{i}\right)+\beta \cdot y \cdot t_{i}+T
$$

If convicted, individuals must pay a monetary fee, $F^{10}$ This fee is related to the level of income. This relation could reflect the wages foregone while serving time in jail, or the reduction in lifetime income due to the stigma attached to convicted criminals: conviction may stigmatize offenders by demonstrating that they are untrustworthy. To the extent that jobs that require trust have better wages, the loss of such jobs will be an additional reason why the fee is related to the

9 This wage subsidy could take the form of minimum wage laws or the prohibition of work by children (which entails the elimination of the lowest wage jobs).

${ }^{10}$ Some crimes are penalized with physical or non-monetary fees: the death penalty or cutting off the criminal's hands or ears are just two examples (since human ears are not traded in normal markets, these fees should be considered non-monetary). I will, however, abstract from these physical penalties in the present analysis. 
level of income. Waldfogel (1992) quantifies the importance of this effect empirically. I will assume that the fee is homogeneous of degree one in the amount of income one gets if not convicted:

(3) $F(\cdot)=c^{n p} \cdot \lambda \cdot \Re\left(t_{i}\right)$

where the fraction of income lost if convicted is $\lambda \cdot f\left(t_{i}\right)$, and $f\left(t_{i}\right)>0, f(0)=0$ and $f^{\prime}\left(t_{i}\right)>0$. In the above, $\lambda$ indicates the severity of the fee per unit of crime and $f\left(t_{i}\right)$ relates the amount of crime to the severity of the penalty. The assumption on the concavity of the penalty is made to ensure that the second order conditions are satisfied. ${ }^{\text {" }}$ Consumption if convicted is therefore

(A) $c^{p}=w\left(1-t_{i}\right)+\beta y \cdot t_{i}+T-F(\cdot)=\left(1-\lambda f\left(t_{i}\right)\right) \cdot\left[w\left(1-t_{i}\right)+\beta y \cdot t_{i}+T\right]$

One feature of this analysis is that, since the probability of being caught is independent of whether the person actually commits crimes or not, he will have to pay the fee with probability $\pi$, even if he sets $t_{i}=0$ (in other words, people could be erroneously prosecuted and convicted).

Since I am assuming that the fee people pay when they commit no crimes is zero $($ as $f(0)=0)$ and, in addition, they do not suffer any disutility from being penalized, then whether innocent people are penalized or not is irrelevant (ie $\mathrm{c}^{\mathrm{p}}\left(\mathrm{t}_{\mathrm{i}}=0\right)=\mathrm{c}^{\mathrm{np}}\left(\mathrm{t}_{\mathrm{i}}=0\right)$ ). Another way to think about the constant probability model is the following: every person faces a probability $\pi$ of being investigated or searched by the police. If searched, the police find out how much crime that person has

11 In fact this could be relaxed and the fee could be allowed to be concave as long as it is not too concave. The exact condition is $f^{\prime \prime}>-(\beta-\omega) \cdot f \cdot(1+\pi) /\left[\pi \cdot c^{n p}\right]$. 
committed and, accordingly, he has to pay a fee. If it turns out that he did not commit any crimes, he pays nothing.

Individuals choose $t_{i}$ so as to maximize utility (1) subject to (2), (3) and (4). The first-order condition entails the equalization of the marginal utility of $t_{i}$ to zero. This condition can be rewritten as:

$$
\text { (5) } M B=\left(\beta-\frac{w}{y}\right) \cdot\left[1-\lambda f\left(t_{i}\right)\right]=M C=\pi \cdot \lambda \cdot \frac{c^{n p}}{y} \cdot f^{\prime}\left(t_{i}\right) \text {. }
$$

If we assume that the maximum possible fee is all income $\left(\lambda f\left(t_{i}\right)<1\right)$, then the term inside the squared brackets is positive. Since the right hand side of (5) is positive, people will devote positive amounts of effort to criminal activities only if $\beta>w / y$. In other words, only if the reward to committing crimes is higher than the reward of spending the same time in a legal activity will people commit crimes. This of course implies that only poor, low wage people will become criminals (rich people can earn more money by working). ${ }^{12}$ The second order condition that ensures this is a maximum is

12 This does not mean that poor people are inherently worse in any sense. I have assumed that everybody has the same preferences towards crime and, therefore, everybody is equally good. The implication of the model comes from the opportunity set faced by both rich and poor. It is more profitable for the rich to be legal and for the poor to be criminal.

Of course I have assumed that the only reward for criminal behavior is the average level of income. It is entirely possible that rich people have access to a better, more rewarding set of criminal activities (white collar crime). If I amended the model to incorporate these factors, the implication would be that, given the size of the criminal reward a particular person faces, he would choose to devote zero time to illegal activities if the wage rate he can earn in legal activities is higher. 


$$
\text { (6) } \frac{\partial^{2} U}{\partial t_{i}^{2}}=-\left(\beta-\frac{w}{y}\right) \cdot f^{\prime}\left(t_{i}\right) \cdot(1+\pi)-\pi \cdot \frac{c^{n p}}{y} \cdot f^{\prime \prime}\left(\hat{l}_{i}\right)<0
$$

In Figure 1 I plot the marginal benefit $\mathrm{MB}$ (which corresponds to the left-hand side of (5)) and marginal cost $\mathrm{MC}$ (which corresponds to the right-hand side of (5)) of criminal behavior. Because the fee is convex, the marginal cost is upward sloping. The marginal benefit is downward sloping. The optimal amount of criminal activity is determined by the crossing of $\mathrm{MB}$ and $\mathrm{MC}$. If they cross at a point where $\mathrm{t}_{\mathrm{i}}$ is between zero and one, the solution will be interior. If they cross to the right of $t_{i}=1$, individuals will become full-time criminals. If they cross to the left of $t_{i}=0$, individuals will devote all their time to legal activities.

\section{(a) The effects of growth on crime.}

Imagine that the average income, the transfer received by potential criminals and the wage rate all increase in the same proportion. The first-order condition says that the amount of crime remains unchanged. In other words, in an economy where the fines, wages and transfers are fully indexed, the amount of crime is invariant to the level of income. The reason is that the rewards and costs of engaging in criminal behavior increase in the same proportion and, therefore, there is no additional incentive or disincentive to perform such activities.

Non-fully-indexed penalty systems, on the other hand, will tend to generate more crime as the economy grows since the rewards for committing crimes grow faster than the penalties. In terms of my analysis, this would correspond to a steady decline of $\lambda$ holding everything else 
constant (I will analyze this case later on). The model, therefore, has no direct prediction on the relation between the amount of crime and the level of income of the economy.

\section{(b) Increase in Income Inequality.}

The process of economic development is sometimes not homogeneous across people: income inequality may increase or decrease as the economy develops. Some people argue that income inequality rises in economies in transition. In fact, this is what leads institutions like the World Bank or the IMF to worry about the introduction of social safety nets.

We can now analyze the effects of an increase in income inequality on the optimal amount of crime. In the present set-up this can be thought of as a reduction in the wage rate, $w$, holding constant the average level of income $y$, or a reduction in w/y. The MB schedule in Figure 1 shifts up while MC shifts down. The result is an increase in the optimal amount of crime. This can be also seen by applying the implicit function theorem to the first-order condition:

$$
\text { (7) } \frac{\partial t_{i}}{\partial(w / y)}=\frac{(1-\lambda \cdot f)+\left(1-t_{i}\right) \cdot f^{\prime} \cdot \pi \cdot \lambda}{\partial^{2} U / \partial t_{i}^{2}}<0
$$

The intuition is that an increase in income inequality reduces the benefits of working in the legal sector, while keeping the gains from crime constant. The obvious optimal reaction is an increase in crime. Hence, models that predict that economic growth is associated with larger income inequality will also predict an increase in disruptive activities. Ehrlich (1973) provides evidence 
supporting this proposition.

\section{(c) Better Law Enforcement.}

Consider now an increase in the probability of conviction. This could be the result of higher investment in police protection or an improvement in the technology used by the police force. In terms of Figure 1, the MC line shifts upward while MB remains unchanged. The total amount of crime goes down. The exact change is given by

$$
\text { (8) } \frac{\partial t_{i}}{\partial \pi}=\frac{\left(c^{n p} / y\right) \cdot f^{\prime} \cdot \lambda}{\partial^{2} U / \partial t_{i}^{2}}<0
$$

Again the intuition is straightforward: a higher probability of being caught and convicted lowers the expected rewards of criminal activity and, therefore, lowers the number of crimes committed.

(d) Larger Fees.

Imagine now that the authorities decide to increase the fees paid for every level of crime. This corresponds to an increase in $\lambda$ in the model. The MB schedule shifts down and MC shifts up. The result is a reduction in the amount of crime. The quantitative change is given by

$$
\text { (9) } \frac{\partial t_{i}}{\partial \lambda}=\frac{\left(\beta-\frac{w}{y}\right) \cdot f+\pi \cdot c^{n p} \cdot \frac{f^{\prime}}{y}}{\partial^{2} U / \partial t_{i}^{2}}<0
$$


When penalties for being convicted are high, crime is low.

(e) More Transfers and/or wage subsidies.

Finally, consider the effect of an increase in transfers (while maintaining average income constant). Because of the linear homogeneity of the fee with respect to income, the marginal benefit of committing crimes does not change. The marginal cost, on the other hand, increases as people who are convicted forego a larger amount of income. The result is a reduction in crime:

$$
\text { (10) } \frac{\partial t_{i}}{\partial(T / y)}=\frac{\lambda \cdot f^{\prime} \cdot \pi}{\partial^{2} U / \partial t_{i}^{2}}<0
$$

Transfers in this model act just like fees since they increase the (opportunity) cost of being penalized: when convicted, people lose a fraction $\lambda f\left(t_{i}\right)$ of their income. Of course, the more they earn the more they lose if convicted. In other words, transfers provide an incentive to stay away from criminal activities by increasing the level of income outside jail. Hence, governments may want to use transfers as a mechanism to bribe people out of crime: when transfers are high, crime does not pay.

Note that this result depends on an increase in transfers relative to income. A certain amount of transfers protect the population against crime, given the amount of income. Income is the prize that criminals obtain by committing crimes. Holding constant the 'degree of protection' (transfers), an increase in the prize (income) induces people to commit more crimes.

Using cross-country data for 40 developed and developing economies, Tabellini (1992) 
finds that the level of transfers per unit of GDP is positively related to the pre-tax level of income inequality, even after he holds constant the initial level of income and the ratio of elderly to total population (both variables are significantly positively related to the level of transfers). He provides a political economy explanation for this finding. The theory outlined in this paper, however, is also consistent with these correlations: income inequality leads to high levels of crime and, therefore, to the need for public welfare protection.

A natural question to ask is why and when would governments go to the trouble of establishing a tax/transfer system instead of just increasing penalties, given that transfers act just like penalties or fees? To answer this question we must bear in mind that there are limits to the fees that governments can impose on people. In particular, people cannot pay more than everything they own. ${ }^{13}$ Suppose that the penalty system is such that the fees paid if caught being a full-time criminal $\left(t_{i}=1\right)$ are everything ${ }^{14}$ Consider that group of people (desperate people) whose wage rate relative to the average is so low that, despite these enormous fees, they decide to become full time criminals (so they pay everything if caught). An increase in fees will not induce these desperate people out of criminal behavior because they will already lose everything if

${ }^{13}$ Here is where the assumption that governments cannot impose non-monetary penalties like death or cutting off people's ears becomes relevant. Presumably the value of lives and ears in terms of income is large enough so that crime can be deterred with the use of these non-monetary penalties only. Countries that have access to these types of drastic penalties (and some Muslim countries do) will not need to use transfers to reduce disruptive behavior. In this paper I will not try to explain why governments do not impose such big non-monetary penalties for seemingly small crimes.

14 People cannot lose exactly everything when they go to jail: the government must provide some level of consumption while in jail. If this was not the case, prisoners would starve to death. This would represent a non-monetary penalty which I assumed was not allowed in this economy. This sentence should therefore say that they lose 'almost' everything. 
convicted. Hence, once people are in such a desperate situation, fees are irrelevant in the sense that higher fees will not decrease criminal behavior. Transfers, on the other hand, will still work as an incentive device to reduce crime because they are not a direct cost but rather an opportunity cost to committing crimes: by increasing the amount of income people receive if they stay out of jail, transfers increase the size of 'everything' to criminals. Hence, they still increase the penalty and, therefore, they still reduce the optimal amount of crime

Note that, in this model where there is no leisure choice, wage subsidies work in much the same way that transfers do. A wage subsidy would increase w relative to $y$. We already established that an increase in w/y reduces crime. Thus, like transfers, wage subsidies work as a crime-reduction device. Note that, also like transfers, what matters is the wage rate relative to the average level of income in the economy. As we saw above, if wages and income increase in the same proportion (along with transfers and fees) the total amount of crime will remain unchanged.

An additional point is that, when people find it optimal to commit crimes under a certain economic environment, it is likely that they will still find it optimal to commit crimes after serving time in jail unless the economic environment has changed. Transfer programs and public subsidies may be a way to change this adverse economic environment. ${ }^{15}$

\section{(f) Extensions of the Model: Making the Probability of Conviction a Function of Crime.}

15 This assumes that people don't learn anything new in jail. It could be the case that criminals did not really know what jail was all about and that an initial period of incarceration shows them how terrible it is. This would increase the perceived penalty and, therefore, reduce the amount of crime in the future. One argument against this is that a lot of criminals come from families and neighborhoods where crimes and criminals are abundant. Hence, it is likely that these people have a pretty good idea of what it is to be in jail so their propensity to commit crimes will not change after having been in jail once before. (see Sah (1991) or evidence on this type of social osmosis). 
Up to now I have assumed that every person was investigated by che police with the same probability $\pi$. This probability was independent of the amount of crime committed. It is natural to assume that the probability of capture and conviction is increasing in the amount of crime a person decides to commit: in the real world, the probability of non-criminals being arrested by mistake is not zero but it is surely smaller than the probability faced by true criminals. Hence, I now assume that $\pi$ is an increasing function of $t_{i}$ with $\pi^{\prime}\left(t_{i}\right)>0, \pi^{\prime \prime}\left(t_{i}\right)<0$ and $\pi(0)=0$. Individuals maximize (1) subject to (2), (3), and (4), taking into account that their actions will affect the probability of being caught:

(11) $\left(\beta-\frac{w}{y}\right) \cdot\left[1-\lambda \cdot f\left(t_{i}\right)\right]-\pi \cdot \lambda \cdot\left[\frac{w}{y} \cdot\left(1-t_{i}\right)+\beta \cdot t_{i}+\frac{T}{y}\right] f^{\prime}\left(t_{i}\right)-\pi^{\prime} \cdot t_{i} \cdot \ln \left(1-\lambda f\left(t_{i}\right)\right) \cdot\left(1-\lambda f\left(t_{i}\right)\right) \cdot\left[\frac{w}{y} \cdot\left(1-t_{i}\right)+\beta \cdot t_{i}+\frac{T}{y}\right]=0$

The first two terms in (11) are the same as in (5). They represent what would be optimal if the probability of capture was unaffected by the choice of $t_{i}$. The third term reflects the marginal losses in utility due to the increase in the probability of capture when people decide to devote one more unit of time to illegal activities. Note that this first-order condition is still invariant to the level of income if the wage rate and the transfer system are fully indexed (that is, if $\mathrm{w} / \mathrm{y}$ and $\mathrm{T} / \mathrm{y}$ are constant). Hence, growth that preserves income inequality still does not have an effect on the level of crime. Using the implicit function theorem, we can see that crime is still increasing in income inequality and decreasing in the size of the penalties. The effect of transfers on crime, on the other hand, is now the following:

(12) $\frac{\partial t_{i}}{\partial(T / y)}=\frac{\pi \cdot \lambda \cdot f^{\prime}-\pi^{\prime} \cdot(1-\lambda \cdot f) \cdot \ln (1-\lambda \cdot f)}{\partial^{2} U / \partial t_{i}^{2}}<0$ 
where $\partial^{2} \mathrm{U} / \partial t_{i}^{2}$ is negative according to the second-order conditions (which are satisfied if $\pi^{\prime \prime}>0$ or if $\pi^{\prime \prime}$ is not too negative). The numerator of (12) is positive: the first term is the product of three positive numbers. The second term is the negative of a product of positive numbers times $\ln (1-\lambda f)$. Since both $\lambda$ and $f\left(t_{i}\right)$ are positive fractions, the number inside the logarithm is less than one and, therefore, the logarithm is negative. Therefore, T/y still acts as a crime-reducing device. The main lesson is that if we allow the probability of capture and conviction to be an increasing function of the amount of crime committed, the relevant features of the model do not change. In particular, transfers are still an opportunity cost of being penalized and, therefore, they act as a crime-preventing device.

(g) Extensions of the Model: Introducing Leisure Choice.

The simple model used up to now treats wage subsidies and transfers in a very symmetric way. The reason is that agents were not allowed to choose the amount of leisure optimally. One could argue that if the choice of leisure is allowed, then a transfer induces people to want to buy more leisure. Of course they do so by reducing the time spent in the activity with the lowest reward: legal work. Wage subsidies (which you can collect only if you work), have an offsetting substitution effect as the relative reward of legal work. Transfers that are not linked to work, however, do not have the substitution effect while they still have the perverse wealth effect. To investigate whether this perverse effect is possible in my model, let me amend the utility function so as to incorporate a preference for leisure:

$$
U=\pi \cdot \ln \left(c^{p}\right)+(1-\pi) \cdot \ln \left(c^{n p}\right)+\psi \cdot \pi \cdot \ln \left(l^{p}\right)+\psi \cdot(1-\pi) \cdot \ln \left(l^{n p}\right)
$$


where $\Psi$ is some discount rate on leisure, $\mathrm{p}^{p}$ is the amount of leisure the agent enjoys if penalized and $l^{n p}$ is the leisure the agent enjoys if not penalized. The time spent working is $\left(1-t_{i}-1\right)$, where $t_{i}$ is still the time devoted to crime (because total time available is still normalized to 1 ). As in the previous section we define $c^{\mathrm{np}}$ and $\mathrm{c}^{\mathrm{p}}$ as follows:

$$
\text { (10) } c^{n p}=w \cdot\left(1-t_{i}-l\right)+\beta \cdot y \cdot t_{i}+T
$$

$$
\text { (15) } c^{p}=\left[1-\lambda f\left(t_{i}\right)\right] c^{n p}
$$

I will assume that part of the penalty for criminal behavior is in terms of lost utility. If we denote the amount of leisure enjoyed when not penalized by $l$ (so $1^{\text {np }}=1$ ), the leisure enjoyed when penalized is: ${ }^{16}$

$$
\text { (16) } l^{p}=\left[1-\lambda f\left(t_{i}\right)\right] \cdot l
$$

Agents choose $l$ and $t_{i}$ so as to maximize utility subject to the constraints above. The first-order conditions entail

$$
\text { (17) }\left(\beta-\frac{w}{y}\right) \cdot\left[1-\lambda f\left(t_{i}\right)\right]-(1+\psi) \cdot \lambda \pi \cdot f^{\prime}\left(t_{i}\right) \cdot\left[\frac{w}{y} \cdot\left(1-t_{i}-l^{*}\right)+\beta t_{i}+\frac{T}{y}\right]=0
$$

where $\mathrm{I}^{\circ}$ is the optimum amount of leisure given by

${ }^{16}$ We could also assume that the fraction of income lost if convicted is different from the fraction of time lost if convicted. The reader can check that the key results remain the same. 


$$
\text { (18) } l^{*}=\frac{\psi}{1+\Psi} \cdot\left[\left(1-t_{i}\right)+\frac{\beta t_{i}+(T / y)}{w / y}\right]
$$

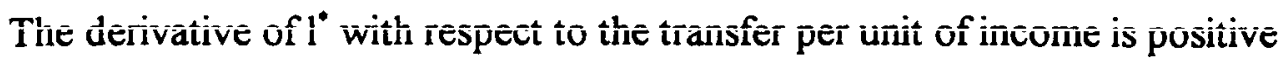

$$
\text { (19) } \frac{\partial l^{*}}{\partial(T / y)}=\frac{\psi}{1+\psi} \cdot \frac{y}{w}>0
$$

Other things being equal, more transfers lead people to enjoy more leisure. Using (19), we can now calculate the effect of an increase in transfers per unit of income on crime

$$
\text { (20) } \frac{\partial t_{i}}{\partial(T / y)}=\frac{(1+\psi) \lambda \pi f^{\prime}\left[1-\frac{w}{y} \frac{\partial l^{*}}{\partial(T / y)}\right]}{\partial^{2} U / \partial t_{i}^{2}}=\frac{\lambda \pi f^{\prime}}{d^{2} u}<0
$$

where $d^{2} u \equiv-(1+\pi) \lambda f^{\prime}\left(\beta-\frac{w}{y}\right)-(1+\psi) \lambda \pi f^{\prime \prime} \frac{c^{n p}}{y}<0$. The first term inside the squared brackets reflects the negative effect of transfers on crime that we outlined in previous sections. The second term inside the brackets, $\frac{w}{y} \frac{\partial l^{*}}{\partial(T / y)}$, reflects the perverse wealth effect that transfers have on the consumption of leisure and, as a result, on crime. Under my particular specification, the overall effect of transfers on crime is unambiguously negative. That is, the perverse wealth 
effect never dominates. ${ }^{17}$

The effect of wage subsidies on crime, on the other hand, does not involve any potentially perverse effects. The reason is that, unlike transfers, wage subsidies have a negative effect on leisure: public transfers in the form of wages, increase the reward to legal activities. The substitution effect induces an increase in work effort and a reduction in crime and leisure. The wealth effect involve an increase in leisure and a reduction in crime and work. The overall effect is a reduction in leisure. The overall effect on crime is given by

$$
\text { (21) } \frac{\partial t_{i}}{\partial(w / y)}=\frac{(1-\lambda f) \cdot \frac{w}{y}+(1+\Psi) \lambda \pi f^{\prime}\left[\left(1-t_{i}-l^{*}\right)-\frac{\partial l^{*}}{\partial(w / y)} \cdot \frac{w}{y}\right]}{\partial^{2} U / \partial t_{i}^{2}}<0
$$

where $\frac{\partial l^{*}}{\partial(w / y)}=-\frac{\psi}{1+\psi} \frac{\beta t_{i}+T / y}{(w / y)^{2}}<0$. Note that all the terms in the numerator of $(21)$ are positive while the denominator is negative. Hence, there is no perverse wealth effect from wage subsidies. $^{18}$

17 This result does not depend on the log utility specification. The overall effect with a utility function of the form $c^{1-\theta} /(1-\theta)$ and $1^{1-\theta} /(1-\theta)$ yields:

$$
\frac{\partial t_{i}}{\partial(T / y)}=\frac{\left[\left(\pi(1-\lambda f)^{1-\theta}+(1-\pi)\right) \cdot w\right]^{\frac{1}{\theta}}}{\left[\pi(1-\lambda f)^{1-\theta}+(1-\pi) \cdot w\right]^{\frac{1}{\theta}}+w \cdot(\pi \psi)^{\frac{1}{\theta}}} \cdot \frac{\pi \lambda f^{\prime}}{\partial^{2} U / \partial t_{i}^{2}}
$$

which is still negative.

18 In a general equilibrium model, wage subsidies may have another perverse effect on crime, as they tend to generate unemployment. Note that this is not the case for transfers. 
The lesson from this section is that, even though we could think that transfers that are not linked to work may have a perverse effect on criminal behavior due to a wealth effect on leisure, the overall effect is still negative. However, the quantitative effects of wage subsidies on crime are likely to be much larger than those of transfers. The main result is still that public welfare should have a negative impact on the amount of time people devote to criminal activities and that the relevant variable is the total spending on public welfare as a ratio to the average income of the economy (which is, in turn, related to the average prize of criminal behavior).

\section{PUBLIC WELFARE, TAXES, AND GROWTH.}

\section{(a) Setup of the Model}

In the previous sections I considered the partial equilibrium effects of aggregate public welfare policies on the criminal behavior of people. The natural question to ask is, given that the government can reduce crime by increasing the size of the public welfare system, why doesn't it get rid of all crime by having an enormous public welfare program?. The answer is, of course, that transfers and subsidies need to be financed by raising taxes. Taxes, in turn, may distort private choices for savings and investment which, in turn, affect the consumption path. The government, therefore, will have to balance the distortionary effects of the implicit 'taxes' imposed by criminals with those of the explicit taxes imposed by the government itself. In this section I use a simple model of growth in order to analyze these issues.

Agents maximize a utility function of the form 


$$
\text { (22) } \int_{0}^{\infty} e^{-\rho \cdot t} \frac{c^{1-\theta}-1}{1-\theta} d t
$$

where $\mathrm{c}$ is the average consumption of the population. There are two ways to think about (22). First we could think that the representative agent does not care about the utility of criminals. Under this interpretation, $\mathrm{c}$ is the average consumption of the non-criminal population. Alternatively, we would think in terms of the veil of ignorance of Harsany and Rawls where, ex-ante, people do not know whether they will end up being criminals or not. If we assume that, ex-ante, all agents are identical, the choice variable c could be interpreted as the level of consumption of the representative or average agent, and (22) then represents his utility.

I will imagine that, as a result of criminal and disruptive activities, some aggregate output is lost. Since most crimes entail just a transfer from victim to criminal (at least this is true for most property crimes) one could think that no aggregate output is lost as a result. There are several reasons, however, why output losses may exist. First, society may not care about the happiness of criminals. If this is the case, any resources that end up in their hands should be considered social losses. Second, victims of crime may be emotionally and physically disrupted. The consequence of such disruption will be a reduction in the victim's ability to perform his job at pre-crime levels. Crime, therefore, lowers labor productivity. Third, private individuals may devote effort, time, and resources to protect themselves against crime. This is a social waste much in the same manner as rent-seeking activities that use up some output for no particularly useful purpose. Fourth, some output may be simply destroyed as a result of criminal activities: at 
the very least, robbers are careless and they break precious pieces of china when they enter somebody's house.

A fraction $1-\varphi(\cdot)$ of income is lost and a fraction $\varphi(\cdot)$ is still available after crime. We can also think of $\varphi(\cdot)$ as the instantaneous probability of maintaining one's property rights on output. According to the analysis above, this fraction or probability will be an increasing function of the overall level of police and legal protection, an increasing function of the size of the penalties for conviction, and a decreasing function of income inequality. Most importantly, it will be an increasing function of the total amount of aggregate transfers or public welfare, TR, per unit of average income. ${ }^{19}$ Since I assume that the population is constant, I can normalize the stock of people to one so average and aggregate income coincide. In order to concentrate on the effects of transfers on growth, let me assume that the fraction $\varphi$ is solely a function of $T R / Y^{\text {ac }}$, where $Y^{\text {ac }}$ is national income 'after-crime'. ${ }^{20}$ In particular, I neglect police protection and public investment in property rights and law enforcement, despite the fact that these are expenditures relevant to criminal activities. Hence, I assume

(23) $\varphi(\cdot)=\varphi\left(\frac{T R}{Y^{a c}}\right)$, with $\varphi^{\prime}(\cdot)>0, \quad \varphi^{\prime \prime}(\cdot)<0, \quad \varphi(0) \geq 0, \quad \varphi(1) \leq 1, \quad \varphi(0)<\varphi^{\prime}(0)$

19 We should think of TR as including not only transfers but also wage subsidies and other kind of public welfare. As we showed in previous sections, all of them affect crime negatively. In the rest of the paper, I use the terms transfers and public welfare interchangeably.

20 Alternatively, it could be assumed that $\varphi()$ is a function of TR per unit if pre-crime income. This alternative specification does not change any of the substantive results. 
where the assumption on the last inequality is made so as to ensure that the problem of crime is important enough to warrant public intervention.

Under this specification, redistributional transfers and public welfare resemble productive public goods subject to congestion: the amount of income people get to keep after crime depends on the level of public welfare relative to the size of criminal threat. This threat, in turn, depends on the prize that criminals get if they decide to commit crimes, which is proportional to national income. When a person increases his economic activity, he raises the economy's average level of income and, with it, it congests the protective power of public welfare (Thompson (1974) and Barro and Sala-i-Martin (1992) interpret national defense spending along similar lines).

I will imagine that the production function is linear in the capital stock

$$
\text { (24) } y^{p c}=A \cdot k
$$

where $y^{p c}$ is per capita "pre-crime" income and $\mathrm{k}$ per capita capital. The linearity of the production function is not essential to my analysis but it enables me to get closed form solutions for growth rates (I could use a neoclassical production function and the growth effects of different policies would be temporary and analytically intractable; the direction of the growth effects along the transitional path would, however, be the same).

The government collects revenue from a constant tax rate on after-crime income $\tau$ (I assume that illegal income does not pay taxes) and always runs a balanced budget. All components of public spending other than transfers are excluded from the present analysis. All public revenue is therefore spent on public welfare. The government budget constraint is: 
(25) $T R=\tau \cdot \varphi\left(\frac{T R}{Y^{a c}}\right) \cdot A K$

where $K$ is the aggregate capital stock and $Y^{a c}=\varphi(\cdot)$ AK is the after=crime aggregate income available to non-criminals. Legal after-tax and after-crime output is devoted to either consumption or investment. The constraint faced by the individual is, therefore

$$
\text { (26) } \dot{k}=(1-\tau) \cdot \varphi\left(\frac{T R}{Y^{a c}}\right) \cdot A \cdot k-c-\delta \cdot k
$$

where $\mathrm{k}_{0}>0$ is given, $\tau$ is the tax rate on 'after-crime' output, and $\delta$ is the constant rate of capital depreciation.

Legal individuals maximize (23) subject to (26). Since all agents are small relative to the aggregate, they all think that their actions do not affect the behavior of the government. Hence, when they optimize they take $\varphi\left(\mathrm{TR} / \mathrm{Y}^{\mathrm{ac}}\right)$ and $\tau$ as given. ${ }^{21}$ The first-order conditions are

$$
\text { (27) } \gamma_{c}=\frac{\dot{c}}{c}=\frac{\left[(1-\tau) \cdot \varphi\left(T R / Y^{a c}\right) \cdot A-\rho-\delta\right]}{\theta}
$$

$$
\text { (28) } \lim _{t \rightarrow \infty} p \cdot k=0
$$

21 I assume that individuals, who own the firms, produce output at home. The results would be the same if there were competitive markets for goods and capital. 
where $p$ is the shadow price associated with the constraint (26). Note that, since $\tau$ is constant, the government budget constraint says that $\mathbb{T R} / Y^{2 c}$ is also constant so transfers and output grow at the same rate. It follows that consumption grows at a constant rate at all points in time. From the budget constraint (26), it can be seen that in the steady state, consumption, physical capital and, therefore, output grow at the same rate $\gamma_{\mathrm{c}}=\gamma_{\mathrm{k}}=\gamma_{\mathrm{y}}=\gamma \equiv \gamma$. The transversality conditions imply that physical capital grows at that same rate at all points in time. Hence, the model displays no transitional dynamics as all variables grow at the same constant rate all the time. We can use (27) to find the growth rate of the economy $y^{22}$

(29) $\gamma=\frac{[(1-\tau) \cdot A \cdot \varphi(\tau)-\rho-\delta]}{\theta}$.

The size of the public welfare program has two effects on the growth rate $\gamma$ : on the one hand higher taxes reduce growth as they distort investment decisions (this is the term (1- $\tau$ ) in (29)); on the other hand they increase growth as they reduce the amount of crime and disruption in the economy (this is the term $\varphi(\tau)$ in (29)). For high levels of $\tau$ (large governments) the first, detrimental effect dominates. For low levels of $\tau$ the second, beneficial effect dominates because $\varphi(0)<\varphi^{\prime}(0)$ (see (23)). In words, if the crime problem when there is no public welfare is important

22 If we assume that $\varphi()$ is a function of TR/Y rather than TR/Y, the growth rate is not a function of $\varphi(\tau)$ but, instead, a function of $\eta(\tau)$ with $\eta^{\prime}(\tau)$. Where $\eta 0$ can be derived as follows: define $\varphi_{2}()$ as the function that satisfies the public budget constraint $\varphi_{2}\left(\right.$ TR/AK) $\equiv \tau$ where $\varphi^{\prime}\left(0^{>0}\right.$ (this follows from the assumptions $\varphi^{\prime \prime}<0$ and $\varphi(0) \geq 0$ ). Invert it and plug in $\varphi(T R / A K)$ to get the growth rate as a function of $\tau$ only where $\eta(\tau)=\varphi\left(\varphi_{2}^{-1}(\tau)\right)$. Since both $\varphi()$ and $\varphi_{2}()$ are monotonically increasing, $\eta^{\prime}(\tau)>0$. 
enough, then an increase in the size of such public programs will increase the growth rate of the economy. If this condition does not hold (so the crime problem is not important), then it could be the case that $\partial \gamma / \partial \tau<0$ for all $\tau$ so the optimal size of the government is $\tau^{*}=0$. Under these circumstances, there is a size of the government $\tau^{\circ}$ at which the two effects exactly cancel out and growth reaches its maximum. The rate $\tau^{*}$ is given by the following implicit function

$$
\text { (30) } \frac{\partial \gamma}{\partial \tau}=-\varphi(\tau *)+(1-\tau *) \cdot \varphi^{\prime}(\tau *)=0
$$

The maximization of growth is not always equivalent to the maximization of the utility of the representative agent. This is true, however, when $\varphi(\cdot)$ takes a Cobb Douglas form.

(c) Superiority of Income Taxes.

It is interesting to compare the outcome of this market economy with that of a planner. Given an arbitrary size of the government, $s=\mathrm{TR} /[\mathrm{AK} \cdot \varphi(\mathrm{TR} / \mathrm{AK})]$, the planner chooses a path of consumption and capital so as to maximize the utility of the representative consumer. The resulting growth rate is

$$
\text { (31) } \gamma_{P L}=\frac{[(1-s) \cdot A \cdot \varphi(s)-\rho-\delta]}{\theta}
$$

where the effect of $s$ on the rate of growth is given by the following expression

$$
\text { (32) } \frac{\partial \gamma_{P L}}{\partial s}=-\varphi(s *)+(1-s *) \cdot \varphi^{\prime}(s *)=0
$$


Note that if a government using income taxes chooses $\tau$ so as to maximize growth $\left(\tau=\tau^{\circ}=s^{\circ}\right.$ ), then the social optimum will be replicated. In other words, if the size of the government is optimal, the proportional income tax is Pareto efficient. It is interesting to see that a shift from income tax to lump-sum tax lowers utility but it increases growth. The growth rate under lump-sum taxes is given by:

$$
\text { (33) } \gamma_{L S}=\frac{[A \varphi(s)-\rho-\delta]}{\theta} \text {, }
$$

Given the size of the government, the growth rate corresponding to lump-sum taxes is always larger than the one the planner would choose. That is, if taxes are lump sum there is overinvestment and excessive growth. The intuition for this result is that, when an individual producer decides to increase capital by one unit, he increases the average output of the economy. This in turn induces criminals to increase their criminal effort since the rewards for crime have increased. In other words, investors congest the protective role of transfers without really taking this into consideration when making investment decisions. Therefore, they tend to overinvest and overcrowd transfers. A lump-sum tax will not do anything to solve this congestion effect. An income tax, on the other hand, acts as a fee for the use of transfers as a crime-preventing device: it internalizes the externality and deters people from investing too much. Thus, from a social point of view, an income tax is superior to a lump-sum tax.

\section{EMIPURICAL EVIDENCE USING CROSS-COUNTRY DATA.}

Let me finish by providing some empirical evidence in favor of the theory developed in this 
paper. The key difference between my model and all other models of transfers is that mine suggests that, because they are 'productive', transfers should affect growth positively. We can check these predictions using cross-country data: IMF's Government Financial Statistics provide data on government transfers for a sample of 75 countries going back to $1970 .{ }^{23}$ I use the ratio of transfers to GDP, along with the growth rates in real per-capita income between 1970 and 1985 from the Summers and Heston data set. I also use the 1970 ratio of public consumption and public investment to GDP and the savings rate constructed by Barro (1991a).

The model predicts that, in a cross-country regression, the growth rate of the economy should be positively related to the size of the transfer program, once the size of the government (which in the model is reflected by $\tau$ ) and proxies for the preference parameters are held constant. This prediction is checked in the first column of Table 1. I proxy the preferences towards savings with the initial (1970) savings rate and the size of the government with the 1970 ratio of total spending to GDP. Initial income is included so as to allow for the possibility of transitional dynamics (recall that I assumed an Ak technology for simplicity but if, instead, the technology is neoclassical, the growth implications of the model are the same for a transitional period. This transition is reflected in the initial level of income). The coefficient is negative and significant $(-.0128$ s.e $=0043)$, which reflects the importance of the transitional process. The key coefficients, however, are the ones on the size of the government, $-.1117($ s.e. $=.0370)$ and the

${ }^{23}$ The GFS transfer variable also includes old-age pensions. In Sala-i-Martin (1992), I show that old-age pensions should ALSO be regarded as productive as they induce unproductive, old people out of their jobs. Hence, I am not too worried about the fact that this may be too broad a measure of transfers. Nevertheless, I think it would be interesting to distinguish empirically which one of the two components of total transfers dominates the results. For most poor countries of this sample, however, separate data on redistributional and intergenerational transfers is not available. 
transfer to GDP ratio .1092 (s.e.=.0509). As expected, holding the overall size of the government, transfers are positively related to per-capita growth. I repeat the experiment in column 2, using the log of TR/Y instead of the level. The overall results are the same (the coefficient on $\log (\mathrm{TR} / \mathrm{Y})$ is $.0050($ s.e. $=.0018))$.

In the model outlined above, I neglected public investment, public consumption and other forms of public spending. Following Barro (1990), we could easily include such variables in the model. As in Barro (1990), the additional predictions would be that productive spending (such as public investment) should be positively related to growth, while non-productive spending (such as public consumption) should affect growth negatively. In column 3, I break the total size of the government into three components: public consumption $(\mathrm{GC} / \mathrm{Y})$, public investment $(\mathrm{GI} / \mathrm{Y})$ and transfers $(\mathrm{TR} / \mathrm{Y})$. Public consumption enters negatively $(-.1285$, s.e. $=.0475)$ and public investment is insignificant $(-.2278$, s.e. $=1728)$. The only variable that is positively related to growth is transfers, with a coefficient of $.1108(\mathrm{~s} . \mathrm{e} .=.0522)$.

These results suggest that, contrary to the predictions of ALL other theories, transfers are positively related to growth rates for a large cross-section of countries.

\section{V. $\mathbb{C O N} C L U S I O N S$.}

In this paper I presented a model that explains the existence of social safety nets in the form of redistributional transfers and wage subsidies. I showed that such transfers are a mechanism to buy poor people out of disruptive activities such as crime, revolutions, or other forms of social disruption. I argued that public welfare is likely to have some effect on crime, especially among those segments of the population that are so poor that the losses of going to jail 
are very small relative to the potential gains from criminal behavior. I also argued that, in aggregate production functions, transfers and other forms of welfare look like productive public inputs subject to congestion which increase the productivity of private capital and, therefore, increase the growth rate of the economy. I then derived the growth-maximizing size of the public welfare system. I showed that, as a result of transfers being 'subject to congestion', an income tax system was superior to a lump-sum tax system. The reason was that income taxes act as user fees on the use of welfare as a protective device. Finally, I provided international evidence in favor of the model: contrary to the predictions of all other theories of transfers, the data suggest that other things equal, countries that have larger transfers programs tend to grow faster. ${ }^{24}$

${ }^{24}$ Using panel data for a sample of 23 OECD countries, Cashin (1995) also finds a positive partial relation between the size of the transfer program and the rate of growth. 


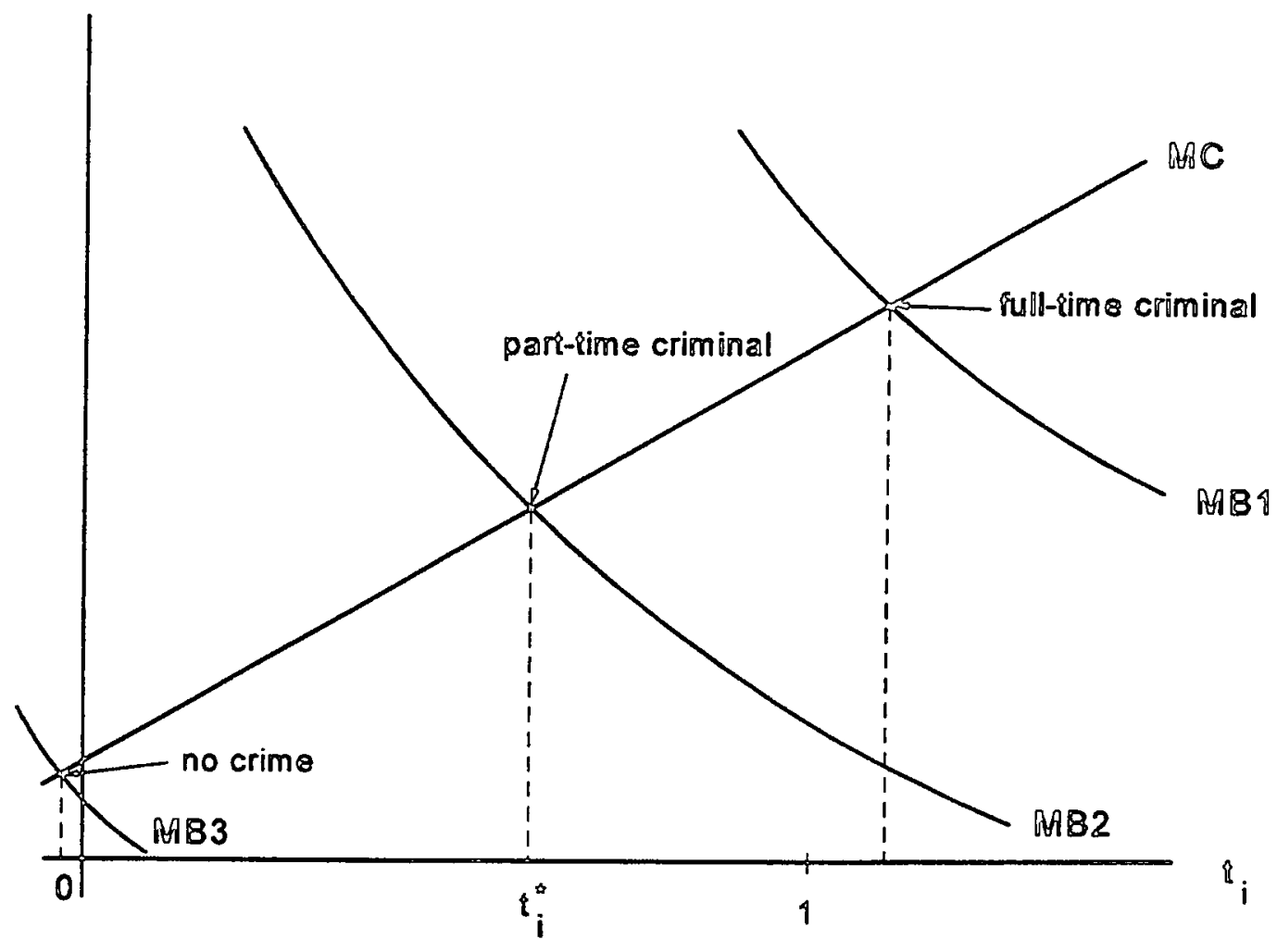

Figurre 1: Optimal criminal behavior. 


\section{Table 1: Growth and Transfers}

\begin{tabular}{|c|c|c|c|}
\hline & $\begin{array}{c}\text { (1) } \\
\text { Growth 1970-1985 } \\
\end{array}$ & $\begin{array}{c}\text { (2) } \\
\text { Growth 1970-1985 } \\
\end{array}$ & $\begin{array}{c}\text { (3) } \\
\text { Growth 1970-1985 }\end{array}$ \\
\hline Constant & $\begin{array}{c}0.0007 \\
(0.0099)\end{array}$ & $\begin{array}{c}0.0251 \\
(0.0138)\end{array}$ & $\begin{array}{c}0.0002 \\
(0.0111)\end{array}$ \\
\hline $\log \left(G D P_{1970}\right)$ & $\begin{array}{l}-0.0128 \\
(0.0043)\end{array}$ & $\begin{array}{l}-0.0133 \\
(0.0037)\end{array}$ & $\begin{array}{l}-0.0147 \\
(0.0049)\end{array}$ \\
\hline$\tau$ & $\begin{array}{l}-0.1117 \\
(0.0370)\end{array}$ & $\begin{array}{l}-0.1093 \\
(0.0356)\end{array}$ & \\
\hline Savings Rate & $\begin{array}{c}0.2006 \\
(0.0357)\end{array}$ & $\begin{array}{c}0.1997 \\
(0.0373)\end{array}$ & $\begin{array}{c}0.2168 \\
(0.0515)\end{array}$ \\
\hline TR/Y & $\begin{array}{c}0.1092 \\
(0.0509)\end{array}$ & & $\begin{array}{c}0.1108 \\
(0.0522)\end{array}$ \\
\hline $\log (\mathrm{TR} / \mathrm{Y})$ & & $\begin{array}{c}0.0050 \\
(0.0018)\end{array}$ & \\
\hline $\mathbf{G C N}$ & & & $\begin{array}{l}-0.1285 \\
(0.0475)\end{array}$ \\
\hline $\mathbf{G I} / \mathbf{Y}$ & & & $\begin{array}{l}-0.2278 \\
(0.1728)\end{array}$ \\
\hline $\mathbf{R}^{2}$ & 0.35 & 0.37 & 0.35 \\
\hline s.e. & 0.0183 & 0.0179 & 0.0182 \\
\hline
\end{tabular}

Notes: Standard Errors are in parenthesis. All regressions have been estimated using White's heteroscedasticity-consistent covariance matrix. The data for GDP and growth rates is from Summers and Heston (1988). GR7085 is the annualized growth rate of per capita GDP. $\ln ($ GDP70) is the logarithm of the 1970 per capita GDP. $\tau$ is a measure of the 1970 ratio of total government spending to GDP and is taken from Barro (1991a). The savings rate is the 1970 ratio of total investment to GDP. R/Y is the average of the ratio of social security transfers to GDP for the period 1970-1985. GC/Y and GI/Y is the ratio of total government consumption (excluding defense and education) and total investment to GDP for 1970. They are taken from Barro (1991a). Sample size: 75 countries. 


\section{REFERENCES.}

Alesina, A. and D. Rodrik (1991), "Redistributive Politics and Economic Growth", NBER WP\# 3668 .

Barro, R. J. (1990), "Government Spending in a Simple Model of Endogenous Growth", Journal of Political Economy, 95, S103-125, October.

Barro, R. J., (1991a), "Economic Growth in a Cross Section of Countries", Quarterly Journal of Economics, May.

Barro (1991b), "A Cross-Country Study of Growth, Saving and Government", in B. Douglas Bernheim and John B. Shoven, eds. National Saving and Economic Performance, Chicago, Chicago University Press.

Barro, R. J. and X. Sala-i-Martin, (1992), "Public Finance in Models of Economic Growth", mimeo Harvard University, Review of Economic Studies, $\$ 59$, p. 645-661, November.

Barro, R. J. and X. Sala-i-Martin, (1995), Economic Growth, McGraw Hill, New York.

Becker, G. S., (1968), "Crime and Punishment: An Economic Approach" Journal of Political Economy, April.

Cashin, P., (1995), "Government Spending, Taxes, and Economic Growth", International Monetary Fund Staff Papers, June, p.237-269.

Chamley, C., (1981), "The Welfare Cost of Capital Income Taxation in a Growing Economy", Journal of Political Economy, 89, 468-496.

Chu, Ke-young and S. Gupta, (1993) "Protecting the Poor: Social Safety Nets during the Transition", Finance and Development, International Monetary Fund, Washington, June.

Ehrlich, I., (1973), "Participation in Illegal Activities", Journal of Political Economy, May.

IMF, (1993), "Social Security Reforms and Social Safety Nets" in Development Issues, prepared by the Joint Ministerial Committe of Boards of Governors of the World Bank abd the International Monetary Fund, \#32.

Lucas, R. E. Jr. (1990), "Supply-Side Economics: An Analytical Review", Oxford Papers, 42, 293-316.

Persson, T. and G. Tabellini, (1991), "Is Inequality Harmful for Growth?", mimeo Berkeley. 
Sala-i-Martin, X., (1995), "A Positive Theory of Socal Security", CEPR working paper, June.

Sah, R. K., (1991), "Social Osmosis and Patterns of Crime", Journal of Political Economy, 99, 6 , December, 1272-1295.

Stark, O. (1995), Morgenstern Lectures, Cambridge University Press.

Stigler, G., (1970), "The Optimal Enforcement of Lawws", Jourmal of Póliticuil Economy, 78, 2, March/April.

Summers, R. and A. Heston, (1988), "A New Set of International Comparisons of Real Product and Price Levels: estimates for 130 countries", Review of Income and Wealth 34, March, $1-25$.

Tabellini, G. (1992), "A Positive Theory of Social Security", mimeo IGIER, Milano.

Thompson, E. A., (1974), "Taxation and National Defense", Journal of Political Economy, 82, July/August, 755-782.

Waldfogel, J. (1992), "The Effects of Criminal Conviction on Income and the Trust Reposed in the Workmen", mimeo Yale University, 1992. 
1. Albert Marcet and Ramon Marimon

Communication, Commitment and Growth. (June 1991) [Published in Joumal of Economic Theory Vol. 58, no. 2, (December 1992)]

2. Antoni Bosch

Economies of Scale, Location, Age and Sex Discrimination in Household Demand. (June 1991) [Published in European Economic Review 35, (1991) 1589-1595]

3. Albert Satorra

Asymptotic Robust Inferences in the Analysis of Mean and Covariance Structures. (June 1991) [Published in Sociological Methodology (1992), pp. 249-278, P.V. Marsden Edt. Basil Blackwell: Oxford \& Cambridge, MA]

4. Javier Andrés and Jaume Garcia

Wage Determination in the Spanish Industry. (June 1991) (Published as "Factores determinantes de los salarios: evidencia para la industria espaffola" in J.J. Dolado et al. (eds.) La industria y el componamiento de las empresas espantolas (Ensayos en homenaje a Gonzalo Mato), Chapter 6, pp. 171-196, Alianza Economia]

5. Albert Marcet

Solving Non-Linear Stochastic Models by Parameterizing Expectations: An Application to Asset Pricing with Production. (July 1991)

6. Albert Marcet

Simulation Analysis of Dynamic Stochastic Models: Applications to Theory and Estimation. (November 1991), 2d. version (March 1993) [Published in Advances in Econometrics invited symposia of the Sixth World Congress of the Econometric Society (Eds. J. Laffont i C.A Sims). Cambridge University Press (1994)]

7. Xavier Calsamiglia and Alan Kirman

A Unique Informationally Efficient and Decentralized Mechanism with Fair Outcomes. (November 1991) [Published in Econometrica, vol. 61,5 , pp. 1147-1172 (1993)]

8. Albert Satorra

The Variance Matrix of Sample Second-order Moments in Multivariate Linear Relations. (January 1992) [Published in Statistics \& Probability Letters Vol. 15, no. 1, (1992), pp. 63-69]

9. Teresa Garcia-Milà and Therese J. McGuire

Industrial Mix as a Factor in the Growth and Variability of States'Economies. (January 1992) [Published in Regional Science and Urban Economics, vol. 23, (1993) pp. 229-241]

10. Walter Garcia-Fontes and Hugo Hopenhayn

Entry Restrictions and the Deternination of Quality. (February 1992)

11. Guillem López and Adam Robert Wagstaff

Indicadores de Eficiencia en el Sector Hospitalario. (March 1992) [Published in Moneda y Crédito Vol. 196]

12. Daniel Serra and Charles ReVelle

The PQ-Median Problem: Location and Districting of Hierarchical Facilities. Part I (April 1992) [Published in Locarion Science, Vol. 1, no. 4 (1993)]

13. Daniel Serra and Charles ReVelle

The PQ-Median Problem: Location and Districting of Hierarchical Facilities. Part II: Heuristic Solution Methods. (April 1992) [Published in Location Science, Vol. 2, no. 2 (1994)]

14. Juan Pablo Nicolini

Ruling out Speculative Hyperinflations: a Game Theoretic Approach. (April 1992) [Forthcoming in Joumal of Economic Dynamics and Controll

15. Albert Marcet and Thomas J. Sargent

Speed of Convergence of Recursive Least Squares Learning with ARMA Perceptions. (May 1992) [Forthcoming in Leaming and Rationality in Economics]

16. Albert Satorra

Multi-Sample Analysis of Moment-Structures: Asymptotic Validity of Inferences Based on Second-Order Moments. (June 1992) [Published in Statistical Modelling and Latent Variables Elsevier, North Holland. K.Haagen, D.J.Bartholomew and M. Deistler (eds.), pp. 283-298.]

Special issue Vernon L. Smith

Experimental Methods in Economics. (June 1992)

17. Albert Marcet and David A. Marshall

Convergence of Approximate Model Solutions to Rational Expectation Equilibria Using the Method of Parameterized Expectations.

18. M. Antònia Monés, Rafael Salas and Eva Ventura

Consumption, Real after Tax Interest Rates and Income Innovations. A Panel Data Analysis. (December 1992)

19. Hugo A. Hopenhayn and Ingrid $M$. Werner

Information, Liquidity and Asset Trading in a Random Matching Game. (February 1993) 
20. Daniel Serra

The Coherent Covering Location Problem. (February 1993) (Forthcoming in Papers in Regional Science)

21. Ramon Marimon, Stephen E. Spear and Shyam Sunder

Expectationally-driven Market Volatility: An Experimental Study. (March 1993) [Forthcoming in Joumal of Economic Theory]

22. Giorgia Giovanneti, Alber Marcet and Ramon Marimon

Growth, Capital Flows and Enforcement Constaints: The Case of Africa. (March 1993) [Published in European Economic Review 37 , pp. 418-425 (1993)\}

23. Ramon Marimon

Adaptive Leaming, Evolutionary Dynamics and Equilibrium Selection in Games. (March 1993) [Published in European Economic Review 37 (1993)]

24. Ramon Marimon and Ellen McGrattan

On Adaptive Learning in Strategic Games. (March 1993) [Forthcoming in A. Kirman and M. Salmon eds. "Leaming and Rationality in Economics" Basil Blackwell]

25. Ramon Marimon and Shyam Sunder

Indeterminacy of Equilibria in a Hyperinflationary World: Experimental Evidence. (March 1993) (Forthcoming in Econometrica]

26. Jaume Garcia and José M. Labeaga

A Cross-Section Model with Zeros: an Application to the Demand for Tobacco. (March 1993)

27. Xavier Freixas

Short Term Credit Versus Account Receivable Financing. (March 1993)

28. Massimo Motta and George Norman

Does Economic Integration cause Foreign Direct Investment? (March 1993) [Published in Working Paper University of Edinburgh 1993:I]

29. Jeffrey Prisbrey

An Experimental Analysis of Two-Person Reciprocity Games. (February 1993) [Published in Social Science Working Paper 787 (November 1992)]

30. Hugo A. Hopenhayn and Maria E. Muniagurria

Policy Variability and Economic Growth. (February 1993)

31. Eva Ventura Colera

A Note on Measurement Error and Euler Equations: an Alternative to Log-Linear Approximations. (March 1993) [Published in Economics Letters, 45, pp. 305-308 (1994)]

32. Rafael Crespi i Cladera

Protecciones Anti-Opa y Concentración de la Propiedad: el Poder de Voto. (March 1993)

33. Hugo A. Hopenhayn

The Shakeout. (April 1993)

34. Walter Garcia-Fontes

Price Competition in Segmented Industries. (April 1993)

35. Albert Satorra i Brucart

On the Asymptotic Optimality of Alternative Minimum-Distance Estimators in Linear Latent-Variable Models. (February 1993) [Published in Econometric Theory, 10, pp. 867-883]

36. Teresa Garcia-Milà, Therese J. McGuire and Robert H. Porter

The Effect of Public Capital in State-Level Production Functions Reconsidered. (February 1993) [Forthcoming in The Review of Economics and Statistics]

37. Ramon Marimon and Shyam Sunder

Expectations and Learning Under Alternative Monetary Regimes: an Experimental Approach. (May 1993)

38. José M. Labeaga and Angel López

Tax Simulations for Spain with a Flexible Demand System. (May 1993)

39. Daniel Serra and Charles ReVelle

Market Capture by Two Competitors: The Pre-Emptive Location Problem. (May 1993) [Published in Joumal of Regional Science, Vol. 34, no.4 (1994)]

40. Xavier Cuadras-Morató

Commodity Money in the Presence of Goods of Heterogenous Quality. (July 1993) [Published in Economic Theory 4 (1994)]

41. M. Antònia Monés and Eva Ventura

Saving Decisions and Fiscal Incentives: A Spanish Panel Based Analysis. (July 1993)

42. Wouter J. den Haan and Albert Marcet

Accuracy in Simulations. (September 1993) [Published in Review of Economic Studies, (1994)] 
63. Jordi Galí

Local Externalities, Convex Adjustment Costs and Sunspot Equilibria. (September 1993) [Forthcoming in Joumal of Economic Theory]

4. Jordi Galí

Monopolistic Competition, Endogenous Markups, and Growth. (September 1993) [Forthcoming in European Economic Review]

45. Jordi Galí

Monopolistic Competition, Business Cycles, and the Composition of Aggregate Demand. (October 1993) [Forthcoming in Joumal of Economic Theory]

\$6. Oriol Amat

The Relationship between Tax Regulations and Financial Accounting: a Comparison of Germany, Spain and the United Kingdom. (November 1993) [Forthcoming in European Management Joumal]

87. Diego Rodríguez and Dimitri Vayanos

Decentralization and the Management of Competition. (November 1993)

48. Diego Rodríguez and Thomas M. Stoker

A Regression Test of Semiparametric Index Model Speciication. (November 1993)

49. Oriol Amat and John Blake

Control of the Costs of Quality Management: a Review or Current Practice in Spain. (November 1993)

50. Jeffrey E. Prisbrey

A Bounded Rationality, Evolutionary Model for Behavior in Two Person Reciprocity Games. (November 1993)

51. Lisa Beth Tilis

Economic Applications of Genetic Algorithms as a Markov Process. (November 1993)

52. Ángel López

The Comand for Private Transport in Spain: A Microeconometric Approach. (December 1993)

53. Ángel López

An Assessment of the Encuesta Continua de Presupuestos Familiares (1985-89) as a Source of Information for Applied Reseach. (December 1993)

54. Antonio Cabrales

Stochastic Replicator Dynamics. (December 1993)

55. Antonio Cabrales and Takeo Hoshi

Heterogeneous Beliefs, Wealth Accumulation, and Asset Price Dynamics. (February 1993, Revised: June 1993)

56. Juan Pablo Nicolini

More on the Time Inconsistency of Optimal Monetary Policy. (November 1993)

57. Lisa B. Tilis

Income Distribution and Growth: A Re-examination. (December 1993)

58. José María Marin Vigueras and Shinichi Suda

A Model of Financial Markets with Default and The Role of "Ex-ante" Redundant Assets. (January 1994)

59. Angel de la Fuente and José Maria Marín Vigueras

Innovation, "Bank" Monitoring and Endogenous Financial Development. (January 1994)

60. Jordi Gali

Expectations-Driven Spatial Fluctuations. (January 1994)

61. Josep M. Argilés

Survey on Commercial and Economic Collaboration Between Companies in the EEC and Former Eastern Bloc Countries. (February 1994) [Published in Revista de Estudios Europeos n 8 (1994) pp. 21-36]

62. German Rojas

Optimal Taxation in a Stochastic Growth Model with Public Capital: Crowding-in Effects and Stabilization Policy. (September 1993)

63. Irasema Alonso

Patterns of Exchange, Fiat Money, and the Welfare Costs of Inflation. (November 1991, Revised: September 1993)

64. Rohit Rahi

Adverse Selection and Security Design. (July 1993, Revised: February 1994)

65. Jordi Gali and Fabrizio Zilibotti

Endogenous Growth and Poverty Traps in a Cournotian Model. (November 1993)

66. Jordi Galí and Richard Clarida

Sources of Real Exchage Rate Fluctuations: How Important are Nominal Shocks?. (October 1993, Revised: January 1994) (Forthcoming in Camegie-Rochester Conference in Public Policy] 
67. John Ireland

A DPP Evaluation of Efficiency Gains from Channel-Manufacturer Cooperation on Case Counts. (February 1994)

68. John Ireland

How Products' Case Volumes Influence Supermarket Shelf Space Allocations and Profits. (February 1994)

69. Fabrizio Zilibouti

Foreign Investments, Enforcement Constraints and Human Capital Accumulation. (February 1994)

70. Vladimir Marianov and Daniel Serra

Probabilistic Maximal Covering Location Models for Congested Systems. (March 1994)

71. Giorgia Giovannetti.

Import Pricing, Domestic Pricing and Market Structure. (August 1993, Revised: January 1994)

72. Raffaela Giordano.

A Model of Inflation and Reputation with Wage Bargaining. (November 1992, Revised March 1994)

73. Jaume Puig i Junoy.

Aspectos Macroeconómicos del Gasto Sanitario en el Proceso de Convergencia Europea. (Enero 1994)

74. Daniel Serra, Samuel Ratick and Charles ReVelle.

The Maximum Capture Problem with Uncertainty (March 1994) [Forthcoming in Environment and Planning B]

75. Oriol Amat, John Blake and Jack Dowds.

Issues in the Use of the Cash Flow Statement-Experience in some Other Countries (March 1994)

76. Albert Marcet and David A. Marshall.

Solving Nonlinear Rational Expectations Models by Parameterized Expectations: Convergence to Stationary Solutions (March 1994)

77. Xavier Sala-i-Martin.

Lecture Notes on Economic Growth (I): Introduction to the Literature and Neoclassical Models (May 1994)

78. Xavier Sala-i-Martin.

Lecture Notes on Economic Growth (II): Five Prototype Models of Endogenous Growth (May 1994)

79. Xavier Sala-i-Martin

Cross-Sectional Regressions and the Empirics of Economic Growth (May 1994)

80. Xavier Cuadras-Morató.

Perishable Medium of Exchange (Can Ice Cream be Money?) (May 1994)

81. Esther Martínez García.

Progresividad y Gastos Fiscales en la Imposición Personal sobre la Renta (Mayo 1994)

82. Robert J. Barro, N. Gregory Mankiw and Xavier Sala-i-Martin.

Capital Mobility in Neoclassical Models of Growth (May 1994)

83. Sergi Jiménez-Martin.

The Wage Setting Process in Spain. Is it Really only about Wages? (April 1993, Revised: May 1994)

84. Robert J. Barro and Xavier Sala-i-Martin

Quality Improvements in Models of Growth (June 1994)

85. Francesco Drudi and Raffaela Giordano.

Optimal Wage Indexation in a Reputational Model of Monetary Policy Credibility (February 1994)

86. Christian Helmenstein and Yury Yegorov.

The Dynamics of Migration in the Presence of Chains (June 1994)

87. Walter García-Fontes and Massimo Motta.

Quality of Professional Services under Price Floors. (June 1994) [Forthcoming in Revista Española de Economia]

88. Jose M. Bailen.

Basic Research, Product Innovation, and Growth. (September 1994)

89. Oriol Amat and John Blake and Julia Clarke.

Bank Financial Analyst's Response to Lease Capitalization in Spain (September 1994) [Forthooming in Intemational Joumal of Accounting.]

90. John Blake and Oriol Amat and Julia Clarke.

Management's Response to Finance Lease Capitalization in Spain (September 1994)

91. Antoni Bosch and Shyam Sunder.

Tracking the Invisible Hand: Convergence of Double Auctions to Competitive Equilibrium. (Revised: July 1994)

92. Sergi Jiménez-Marin

The Wage Effect of an Indexation Clause: Evidence from Spanish Manufacturing Firms. (August 1993, Revised: September 1994) 
93. Albert Carreras and Xavier Tafunell.

National Enterprise. Spanish Big Manufacturing Firms (1917-1990), between State and Market (Septembar 1994)

94. Ramon Fauli-Oller and Massimo Motta.

Why do Owners let their Managers Pay too much for their Acquisitions? (October 1994)

95. Marc Sáez Zafra and Jorge V. Pérez-Rodriguez.

Modelos Autorregresivos para la Varianza Condicionada Heteroscedástica (ARCH) (October 1994)

96. Daniel Serra and Charles ReVelle.

Competitive Location in Discrete Space (November 1994) [Forthcoming in Zvi Drezner (ed.): Facility Location: a Survey of Applicarions and Methods. Springer-Verlag New York.

97. Alfonso Gambardella and Walter Garcia-Fontes.

Regional Linkages through European Research Funding (October 1994) [Forthcoming in Economic of Innovation and New Technology]

98. Daron Acemoglu and Fabrizio Ziliboui.

Was Prometheus Unbound by Chance? Risk, Diversification and Growth (November 1994)

99. Thierry Foucault.

Price Formation and Order Placement Strategies in a Dynamic Order Driven Market (Revised: June 1994)

100. Ramon Marimon and Fabrizio Ziliboti.

'Actual' versus 'Virtual' Employment in Europe: Why is there Less Employment in Spain? (December 1994)

101. Maria Sáez Marí.

Are Large Windows Efficient? Evolution of Learning Rules in a Bargaining Model (December 1994)

102. Maria Sáez Martí.

An Evolutionary Model of Development of a Credit Market (December 1994)

103. Walter Garcia-Fontes and Ruben Tansini and Marcel Vaillant.

Cross-Industry Entry: the Case of a Small Developing Economy (December 1994)

108. Xavier Sala-i-Marin.

Regional Cohesion: Evidence and Theories of Regional Growth and Convergence (October 1994)

105. Antoni Bosch-Domènech and Joaquim Silvestre.

Credit Constraints in General Equilibrium: Experimental Results (December 1994)

106. Casey B. Mulligan and Xavier Sala-i-Martin.

A Labor-Income-Based Measure of the Value of Human Capital: an Application to the States of the United States. (March 1994, Revised: December 1994)

107. José M. Bailén and Luis A. Rivera-Bátiz.

Human Capital, Heterogeneous Agents and Technological Change (March 1995)

108. Xavier Sala-i-Martin.

A Positive Theory of Social Security (Revised: February 1995)

109. J. S. Marron and Frederic Udina.

Interactive Local Bandwidth Choice (February 1995)

110. Marc Sáez and Robert M. Kunst.

ARCH Patterns in Cointegrated Systems (March 1995)

111. Xavier Cuadras-Morató and Joan R. Rosés.

Bills of Exchange as Money: Sources of Monetary Supply during the Industrialization in Catalonia (1844-74) (April 1995)

112. Casey B. Mulligan and Xavier Sala-i-Martin.

Measuring Aggregate Human Capital (October 1994, Revised: January 1995)

113. Fabio Canova.

Does Detrending Matter for the Determination of the Reference Cycle and the Selection of Tuming Points? (February 1994, Revised:

March 1995)

114. Sergiu Hart and Andreu Mas-Colell.

Bargaining and Value (July 1994, Revised: February 1995) [Forthcoming in Econometrica]

115. Teresa Garcia-Milà, Albert Marcet and Eva Ventura.

Supply Side Interventions and Redistribution (June 1995)

116. Robert J. Barro and Xavier Sala-i-Martin.

Technological Diffusion, Convergence, and Growth (May 1995)

117. Xavier Sala-i-Martin.

The Classical Approach to Convergence Analysis (June 1995) 
118. Serguei Maliar and Vitali Perepelitsa.

LCA Solvability of Chain Covering Problem (May 1995)

119. Serguei Maliar, Igor' Kozin and Vitali Perepelitsa.

Solving Capability of LCA (June 1995)

120. Antonio Ciccone and Robert E. Hall.

Productivity and the Density of Economic Activity (May 1995) [Forthcoming in American Economic Review]

121. Jan Werner.

Arbitrage, Bubbles, and Valuation (April 1995)

122. Andrew Scott.

Why is Consumption so Seasonal? (March 1995)

123. Oriol Amat and John Blake.

The Impact of Post Industrial Society on the Accounting Compromise-Experience in the UK and Spain (July 1995)

124. William H. Dow, Jessica Holmes, Tomas Philipson and Xavier Sala-i-Marin.

Death, Tetanus, and Aerobics: The Evaluation of Disease-Specific Health Interventions (July 1995)

125. Tito Cordella and Manjira Datta.

Intertemporal Cournot and Walras Equilibrium: an Ilustration (July 1995)

126. Albert Satorra.

Asymptotic Robustness in Multi-Sample Analysis of Multivariate Linear Relations (August 1995)

127. Albert Satorra and Heinz Neudecker.

Compact Matrix Expressions for Generalized Wald Tests of Equality of Moment Vectors (August 1995)

128. Marta Gómez Puig and José G. Montalvo.

Bands Width, Credibility and Exchange Risk: Lessons from the EMS Experience (December 1994, Revised: June 1995) [Finance and Banking Discussion Papers Series (1)]

129. Marc Sáez.

Option Pricing under Stochastic Volatility and Stochastic Interest Rate in the Spanish Case (August 1995) Finance and Banking Discussion Papers Series (3)]

130. Xavier Freixas and Jean-Charles Rochet.

Fair Pricing of Deposit Insurance. Is it Possible? Yes. Is it Desirable? No (January 1995, Revised: June 1995) [Finance and Banking Discussion Papers Series (4)]

131. Heinz Neudecker and Albert Satorra.

The Algebraic Equality of Two Asymptotic Tests for the Hypothesis that a Normal Distribution Has a Specified Correlation Matrix (April 1995)

132. Walter Garcia-Fontes and Addo Geuna.

The Dynamics of Research Networks in Brite-Euram (January 1995, Revised: July 1995)

133. Jeffrey S. Simonoff and Frederic Udina.

Measuring the Stability of Histogram Appearance when the Anchor Position is Changed (July 1995) [Forthcoming in Computational Statistics and Data Analysis]

134. Casey B. Mulligan and Xavier Sala-i-Martin.

Adoption of Financial Technologies: Implications for Money Demand and Monetary Policy (August 1995) [Finance and Banking Discussion Papers Series (5)]

135. Fabio Canova and Morten O. Ravn.

International Consumption Risk Sharing (March 1993, Revised: June 1995) [Finance and Banking Discussion Papers Series (6)]

136. Fabio Canova and Gianni De Nicolo'.

The Equity Premium and the Risk Free Rate: A Cross Country, Cross Maturity Examination (April 1995) [Finance and Banking Discussion Papers Series (7)]

137. Fabio Canova and Adbert Marcet.

The Poor Stay Poor: Non-Convergence across Countries and Regions (October 1995)

138. Etsuro Shioji.

Regional Growth in Japan (January 1992, Revised: October 1995)

139. Xavier Sala-i-Martin.

Transfers, Social Safety Nets, and Economic Growth (September 1995) 